This is a paper published in ENVIRONMENTAL PRACTICE. This paper has been peer-reviewed and includes the final publisher proofcorrections and journal pagination

Citation for the published paper:

Skärbäck, E. (2007) Noise measurements and rail traffic development: a Swedish case study. Environmental Practice. Volume: 9, Number: 2, pp 119-127.

http://dx.doi.org/10.1017/S1466046607070184

Access to the published version may require journal subscription.

Published with permission from: Cambridge University Press

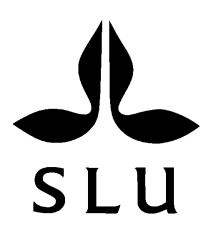

Epsilon Open Archive http://epsilon.slu.se 


\section{Noise Measurements and Rail Traffic Development: A Swedish Case Study}

\author{
Erik Skärbäck
}

Public involvement in the planning process is a prerequisite for democratic outcomes. Environmental issues regarding impacts of sound tend to be limited to mere exercises in noise estimation and guideline values. Such information is difficult for the layman to understand, and such a lack of understanding produces shortcomings in the democratic process. In addition to decibel calculations interpretable by experts, the sonic environment also can be described in more accessible ways. This article reports on a concrete planning case, the widening of the railway through Åkarp in southern Sweden, where the usual calculations of equivalent noise and maximum noise are undergoing critical analysis. In order to complement the noise description, a new measurement has been devised, "high noise time," which is equal to the total time per 24 hours in which trains pass through a place without stopping. The frequency and duration of the passing of trains may be a better measure of disturbance than the maximum noise peak per passage or the equivalent (average) noise level distributed over 24 hours. Film technology also has been developed as a method for recording the frequency and duration of train passage.

Environmental Practice 9:1-9 (2007)

$\mathbf{T}$ his study shows how the use of decibel values, which are difficult to understand, has become an obstacle when dealing with relatively extreme noise situations. The article also compares and analyzes the evaluations of various traffic situations.

Research has shown that peace and quiet are important components for an individual's positive perception of his/ her surroundings. The World Health Organization (2001) states,

The noise problems of the past are incomparable with those plaguing the modern society: the roar of aircraft, the thunder of heavily laden lorries and the thumps and whines of industry provide a noisy background to our lives. But such noise can be not only annoying but also damaging to the health, and is increasing with economic development.

It is therefore important to ensure that future infrastructure projects will be even better planned than today's projects so that our children will not be drowned by noise, "[e]nsuring that environmental, including health, considerations are thoroughly taken into account in the development of plans and programmes" (Economic Commission for Europe, 2003).

Rail traffic has increased to previously-unseen levels in the southwestern part of Skåne County in southern Sweden (see Figure 1). Disturbance surveys are inadequate with regard to traffic quantities of high magnitude, which is why socio-medical effects may not have been taken fully into consideration.

Sweden has long used what is, by international standards, a very high threshold value for the "equivalent" (or average, over 24 hours) noise level of exposure to rail traffic: 60 decibels adjusted, or dBA. ${ }^{1}$ The fact that trains are infrequent at night accounts for the continuance of this decades' old "bonus" of $5 \mathrm{dBA}$ that rail traffic holds over road traffic. Alternatively, Sweden has another threshold value, maximum noise level of exposure (7o dBA), which states that the impact of noise from passing trains upon human dwellings may not exceed $70 \mathrm{dBA}$.

Calculation models are used to estimate equivalent noise and maximum noise; the Swedish Parliament, Riksdagen, has decided on guideline values for each. These values are, however, non-mandatory. The Swedish Environmental Code

Affiliation of author: Department of Landscape Planning, Swedish University of Agricultural Sciences, Alnarp, Sweden

Address correspondence to: Erik Skärbäck, Professor in Regional Planning, Department of Landscape Planning, Swedish University of Agricultural Sciences, 23053 Alnarp, Sweden; (e-mail) Erik.Skarback@lpal.slu.se. (C) 2007 National Association of Environmental Professionals 


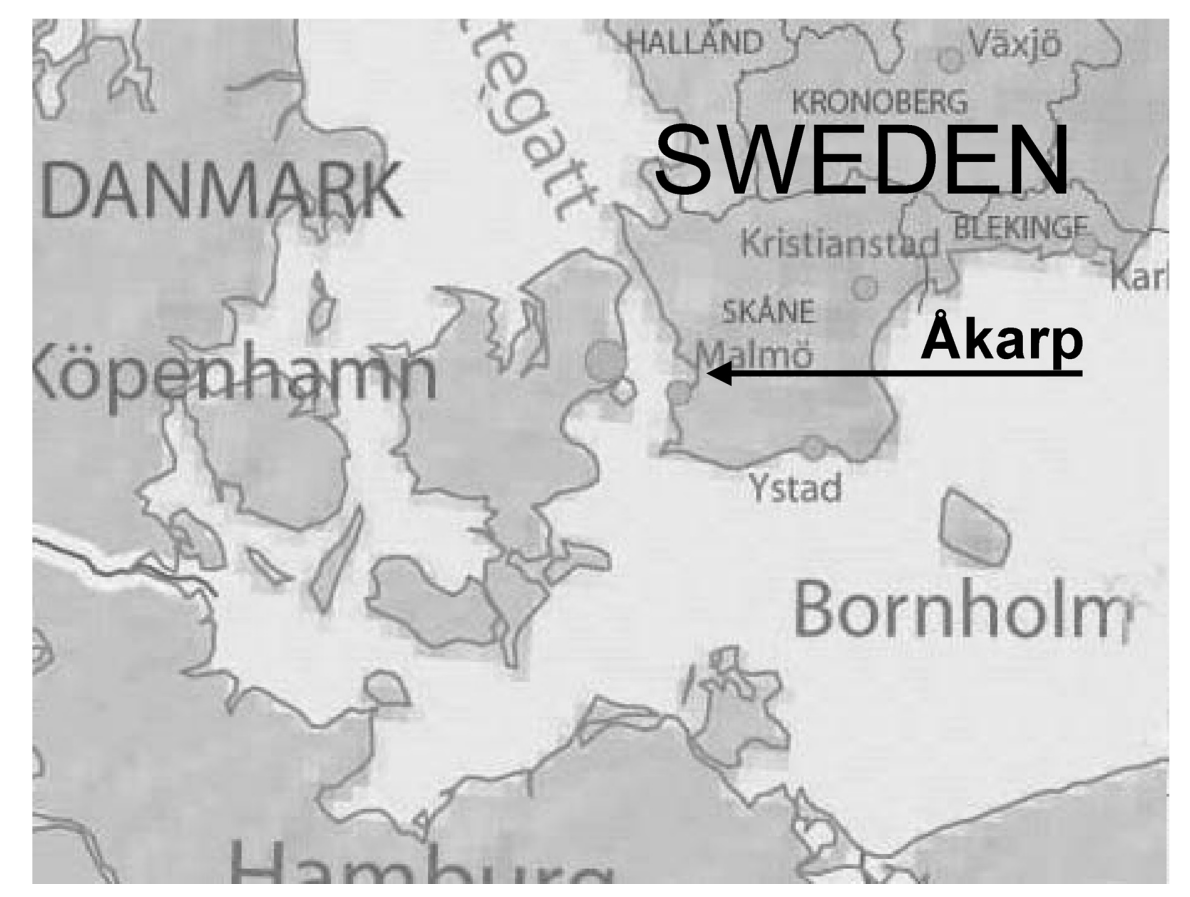

Figure 1. The study area, centering around Åkarp, southwestern Skåne County, in the south of Sweden.

provisions do not require conformity to specified levels of calculated noise. Instead, the Code mandates that environmental effects must not be damaging to health. Research dating back several decades has demonstrated a connection between the levels of average noise and perceived disturbance; the guideline values are based on this information. Subsequently, other research has shown that people also have a need for peace and silence. In a number of studies, Grahn and others have described eight different outdoor environmental characteristics that have been shown to correspond to people's fundamental needs. Four of these characteristics presume low noise, or, defined differently, a relatively high degree of silence. These characteristics are "serene," "wild," "spacious" ("to enter into another world"), and "the pleasure garden" (Grahn, Stigsdotter, and BerggrenBärring, 2005).

The general public's participation in physical planning is a prerequisite for democratic outcomes, but sonic environmental issues tend to be limited to mere calculations of noise levels using various decibel measures. It is difficult for the public to understand what the various decibel values mean in practice, and those who fail to understand cannot participate adequately in the planning process. The affected public needs complementary descriptions of the sonic environment in terms that they can understand. This article reports on experiences from an actual case, the planning of the railway line through Åkarp-a densely populated area between Malmö and Lund in southwestern Skåne (see Figure 1)—where the Swedish communication network funnels down to the European continent. Åkarp is surrounded by two noisy motorways (see Dufort, 2004); one railroad goes straight through the town, dividing it in two. In this case study, regular calculations of equivalent noise made by Banverket (the public authority with responsibility for the Swedish railway network) and their consultant have been complemented with estimates of "high noise time," a new measurement I devised at the request of Burlöv Municipality, the small municipality in which the town of Akarp is situated. My definition of high noise time is the total time throughout a 24 -hour period in which trains pass through without stopping, thus exposing people living close to the railroad to high noise levels. In my opinion, high noise time is easier to understand and compare across different railroads than is the equivalent noise measure, which is a mathematical average of the noise dose.

As previously indicated, Sweden has an established maximum noise guideline value of $70 \mathrm{dBA}$. If the intensity of the noise distribution is equalized at $70 \mathrm{dBA}$, then the time (that is, the duration) during which the noise continues 
will become the decisive variable. What is more, the high noise duration not only indicates the duration of noise, but also its opposite, the "duration of quiet time."

From a democratic perspective, it is important that analyses regarding sound answer the questions posed by the people concerned. People do not ask for decibel values. People ask questions like, "How often or how long should I expect conversations to be broken off as a result of passing trains?" "How often will I be woken up during the night?" "Will I be allowed a half-hour or a one-hour peaceful walk in the evening after a stressful day at work?" "Will I be able to have, in my immediate surroundings, a 'serene,' 'wild,' or 'spacious' experience, to enter into another world, and will it be possible to experience peace in my garden?" The equivalent noise guideline values do not convey any sense of the frequency or duration of the noise events or silences.

\section{The Case Study}

\section{Rapid Increase in Rail Traffic in the Öresund Region}

Train travel in Skåne has doubled during the period 19992004. This represents a $15 \%$ increase in travelers each year. The total number of trains has increased by $21 \%$ over the past five years. One strategy to cope with the travel increase so far has been to fill previously half-full trains. The same period has seen a $19 \%$ increase in the number of freight trains through Åkarp.

A European Union report forecasts that, in the future, the Öresund Region in southern Sweden will become one of three logistics centers in Europe. The Malmö harbor area is expected to double its current size, from 1.5 to 3 million $\mathrm{m}^{2}$, when the excavation residues from construction of the City Tunnel through Malmö are used to fill the low water area adjacent to the present harbor. Preliminary planning is underway to build a Freight Train Bypass Line around the Lund and Malmö urban areas; however, substantial quantities of freight must be transported into the Malmö International Railway Station. Such freight must pass through the municipality of Burlöv twice, once going into Malmö, and again going out.

\section{Banverket's Focus and Responses}

At an early stage, Burlöv Municipality pointed out to Banverket that the development of Malmö into a logistics center for Northern Europe would lead to a massive increase in the freight train flow, in addition to the substantial increase in passenger trains caused by development of the Öresund Region. Banverket responded to this forecast with a confusing display of noise calculations and statements concerning disturbances varying in relation to different equivalent noise values (Banverket, 2004). In the Environmental Impact Report, an increase of 30 to 40 freight trains through Åkarp (from 70-80 to 100-120) was forecast to increase the 24-hour equivalent level by $1 \mathrm{dBA}$. This may be correct, because $3 \mathrm{dBA}$ corresponds to a doubling of the noise level. What was bewildering, however, was that the consultant called this $1 \mathrm{dBA}$ increase an "extremely marginal change in impact." The noise consultant furthermore stated that a potential subsequent twofold increase, from 120 to 240 freight trains, would entail a 2 $\mathrm{dBA}$ increase in the 24-hour equivalent noise level, which was described as a "barely audible change." Burlöv Municipality found this estimate most surprising, given that 240 freight trains is a very large number.

In an attempt to appease the municipality, Banverket offered them sound protection banks and walls similar to those that had been erected in Kallhäll, outside Stockholm. When the municipality inspected the Kallhäll traffic situation more closely, they found that only three freight trains pass through there per week, as compared to Burlöv's 79 freight trains per 24 hours.

\section{Burlöv Municipality Requires More Understandable Data}

This discovery caused Burlöv Municipality to call for their own reasonability assessment of the extent of the traffic and ensuing noise. My role was to carry out a comparison with existing traffic situations elsewhere. From Banverket's own systems department, traffic statistics were collected for locations boasting the heaviest Swedish rail traffic, and data also were collected from the Danish National Rail Administration (Banestyrelsen) concerning Tårnby, located between the Öresund Bridge and Copenhagen (the railway was transformed into a tunnel line through Tårnby in connection with the construction of the Öresund Bridge). Traffic figures were subdivided into three categories: freight trains, non-stop passenger trains, and stopping passenger trains (see Table 1).

The passage of freight trains and that of non-stop passenger trains is perceived as a high noise experience, as opposed to the very low noise of stopping trains. The duration of "high noise" from non-stop passenger trains was esti- 
Table 1. Number of trains per 24 hours (based on a weekly average) through stations with heavy traffic loads in Sweden and Denmark, based on statistics from Swedish Banverket and Danish Banestyrelsen, autumn 2004

\begin{tabular}{lcccc}
\hline & $\begin{array}{c}\text { Freight } \\
\text { trains }\end{array}$ & $\begin{array}{c}\text { Non-stop passenger } \\
\text { trains: express } \\
\text { trains or other } \\
\text { trains that } \\
\text { do not stop }\end{array}$ & $\begin{array}{c}\text { Stopping trains: } \\
\text { commuter trains, } \\
\text { "pågatå, Öresund } \\
\text { trains, or fast } \\
\text { trains that stop }\end{array}$ & $\begin{array}{c}\text { Total } \\
\text { number } \\
\text { of trains }\end{array}$ \\
\hline Katation & 0.5 & 53 & 135 & 188 \\
Häggvik (4-track to Märsta) & 11 & 269 & 141 & 421 \\
Stockholm City & 23 & $10^{\text {a }}$ & 751 & 784 \\
Stockholm South & 23 & 150 & 283 & 456 \\
Tårnby near Kastrup (tunnel) & 16 & 24 & 126 & 166 \\
Frövi-Hallsberg & 48 & 9 & 67 & 124 \\
Lerum & 42 & 75 & 75 & 192 \\
Åkarp & 69 & 183 & 83 & 335 \\
\hline aAll fast trains stop at Stockholm City. Only a small number of work trains pass through without stopping. The number 10 is \\
assumed.
\end{tabular}

mated at 6 seconds, and 36 seconds from freight trains. This duration was observed empirically onsite near the railway line in Akarp. The total duration of all the trains was calculated per 24 hours. The current high noise time periods thus calculated are illustrated in Table 2, whose statistics are also shown as a bar graph in Figure 2.

Thus, Kallhäll, the station that Banverket tried to present as the model for Burlöv to follow, has less than one-tenth the duration of high noise as compared with Åkarp. Tårnby in Denmark, where the tunnel was built, has only onefifth the duration of high noise. Stockholm North (Märsta Line) and Stockholm South have about half the high noise duration, as well as Sweden's so-called "freight waist," Frövi-Hallsberg, and the Gothenburg region (Lerum). Representatives have consistently described Gothenburg as the "freight gateway to the world" and Lerum's heavy noise load has been well attested to and scientifically explored by environmental health experts (Öhrström \& Barregård, 2005).

Table 2. High noise time per 24 hours for stations with heavy traffic loads (up to $100 \mathrm{dBA}$ on the platform)

\begin{tabular}{lcccc}
\hline & \multicolumn{2}{c}{ High noise time, minutes } & & \\
\cline { 2 - 3 } & $\begin{array}{c}\text { Freight trains } \\
(\mathbf{0 . 6} \text { minutes/ } \\
\text { passage })\end{array}$ & $\begin{array}{c}\text { Non-stop } \\
\text { passenger trains } \\
(\mathbf{0 . 1} \text { minutes/ } \\
\text { passage })\end{array}$ & $\begin{array}{c}\text { Total, minutes of } \\
\text { high noise/24 hours } \\
\text { (non-stop trains) }\end{array}$ & $\begin{array}{c}\text { Total, hours of } \\
\text { high noise/ } \\
\text { Station }\end{array}$ \\
\hline Kallhäll & 0.3 & 5.3 & 5.6 & 0.09 \\
Häggvik & 6.6 & 26.9 & 33.5 & 0.56 \\
Stockholm City & 13.8 & 1 & 14.8 & 0.25 \\
Stockholm South & 13.8 & 15 & 28.8 & 0.48 \\
Tårnby (tunnel) & 9.6 & 2.4 & 12.0 & 0.2 \\
Frövi-Hallsberg & 28.8 & 0.9 & 29.7 & 0.50 \\
Lerum & 25.2 & 7.5 & 32.7 & 0.55 \\
Åkarp & 41.4 & 18.3 & 59.7 & 1.00 \\
\hline
\end{tabular}




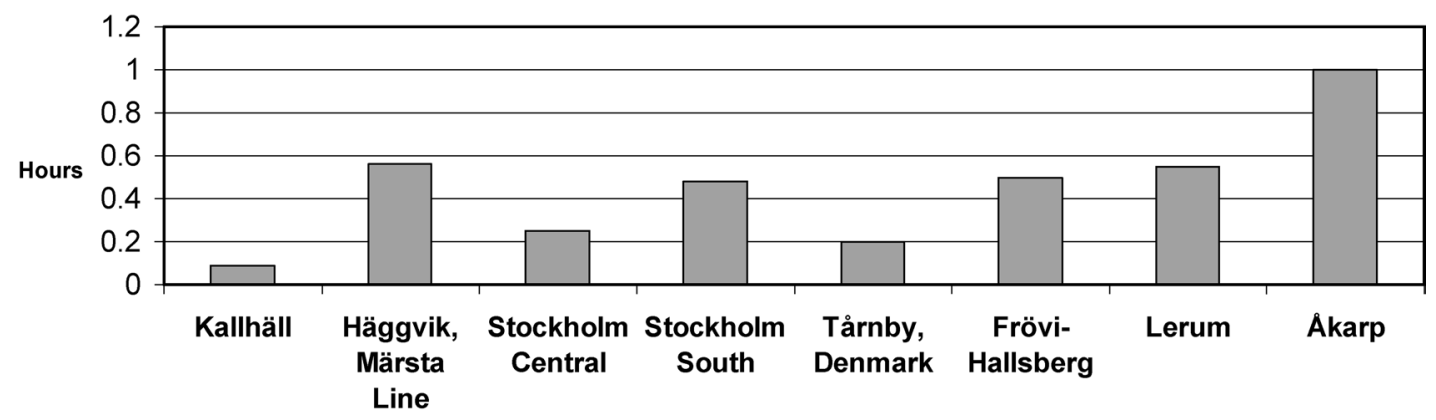

Figure 2. Hours of high noise per 24 hours for stations with heavy traffic loads.

\section{Surprising Results}

The High Noise Parameter versus Equivalent Noise

Everyone involved appeared to be surprised by the fact that the railway stations between Malmö and Lund are apparently the locations with the heaviest train noise loads in all of Sweden. This is remarkable, given that Banverket has such high-standard traffic statistics and that the state priorities for noise protection investments must in all likelihood be related to needs. This general overview of the nationwide differences, disclosed through my relatively simple high noise calculations, either did not exist at Banverket or did exist but was never divulged.

The statistics show that the assessment "extremely marginal change in impact" in relation to a $1 \mathrm{dBA}$ equivalent noise increase must be called into question. The increase of $30-40$ freight trains per 24 hours alone is more than today's total number of freight trains on several heavily-used Swedish railway lines (see Table 1, e.g., Lerum). A survey has been carried out in Lerum by the Department of Occupational and Environmental Medicine, University of Gothenburg (Öhrström \& Barregård, 2005). It reports on the Lerum population's intense irritation over what they con- sider disturbing train noise. At $51-55 \mathrm{~dB}_{\text {ekv }}, 37 \%$ responded "rather disturbed," "very disturbed," and "extremely disturbed" and at $56-60 \mathrm{~dB}_{\text {ekv, }}, 58 \%$ made the same distinctions. ${ }^{2}$ That report hardly would characterize $30-40$ freight trains as an "extremely marginal change in impact."

Banverket's railway report concerning the Southern Trunk Line, Håstad-Arlöv route, forecasts intervals for the highest and lowest potential development by 2020 (Banverket, 2004). Assuming medium values of these intervals, the result is an increase of approximately $42 \%$, without a Freight Train Bypass Line, in the number of trains through Åkarp by the year 2020 (up from today's 335 trains) and an increase of approximately $50 \%$ with a Freight Train Bypass Line (see Table 3). A separate review of freight traffic development in the report reveals that Banverket is counting on a mere $9 \%$ increase if the Freight Train Bypass Line is not constructed, which is considerably less than the most recent developments show. Taking into consideration the development of Malmö Harbor into a major logistics center in Northern Europe, the modest forecast appears unrealistically low. If the Freight Train Bypass Line were constructed, the Banverket 2020 forecast amounts to a $60 \%$ increase. Traffic development in the long term has been investigated by an independent consultant (Inregia, 2005). The fastest forecast alternative,

Table 3. Traffic development forecast for Åkarp in 2020, according to the Banverket railway report for the Håstad-Arlöv route

\begin{tabular}{lccc}
\hline & Freight trains & $\begin{array}{c}\text { Passenger } \\
\text { trains }\end{array}$ & Total \\
\hline $\begin{array}{l}\text { Akarp in 2020, according to Banverket, without } \\
\text { GTBL (Freight Train Bypass Line) }\end{array}$ & $\begin{array}{c}70-80 \text { (a } 9 \% \text { increase } \\
\text { from the present) }\end{array}$ & $350-450$ & $\begin{array}{c}420-530 \text { (a } 42 \% \text { increase } \\
\text { from the present) }\end{array}$ \\
$\begin{array}{l}\text { Akarp in 2020, according to Banverket, including } \\
\text { GTBL (Freight Train Bypass Line) alt. 1 }\end{array}$ & $\begin{array}{c}100-120 \text { (a 60\% increase } \\
\text { from the present) }\end{array}$ & $350-450$ & $\begin{array}{c}450-570 \text { (a } 50 \% \text { increase } \\
\text { from the present) }\end{array}$ \\
\hline
\end{tabular}




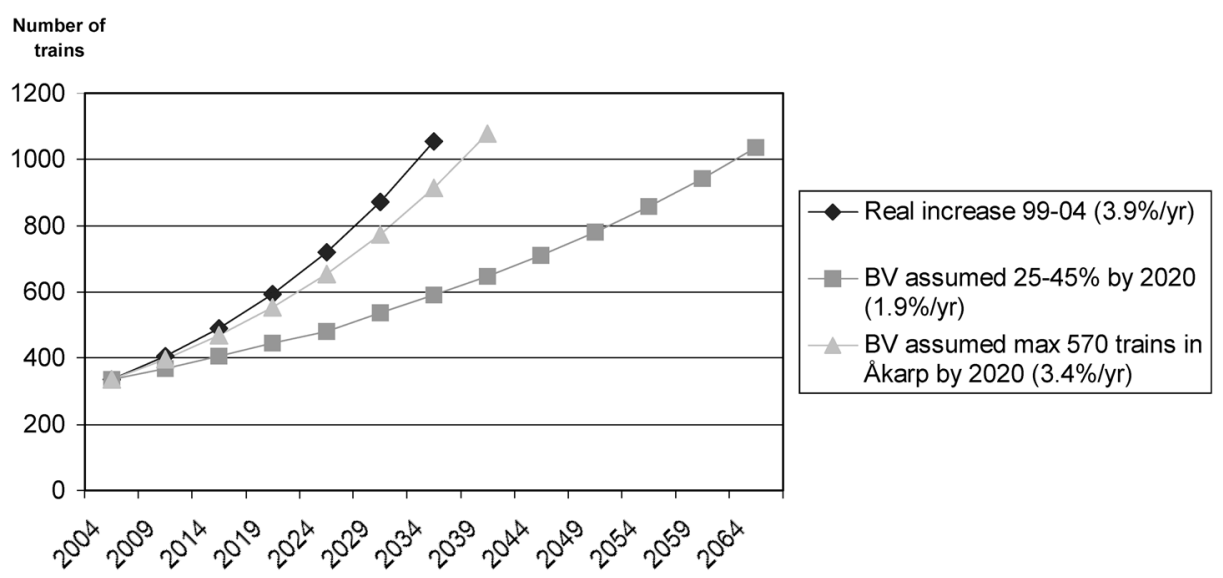

Figure 3. Traffic increase in number of trains per 24 hours in Arlöv and Åkarp; BV = Banverket.

corresponding to an actual traffic increase of 3.9\% from 1999-2004, implies that a 900-train scenario (approximately full capacity) will be attained as early as the 2030s; see Figure 3. If, conversely, Banverket's lowest forecast is assumed (a total traffic increase of $1.9 \%$ ), the ceiling will be hit in the 2050 s.

The illustration of today's high noise time situation in Figure 2 may serve as a model for a forecast of the future situation; see Figure 4. In the future, Akarp will further

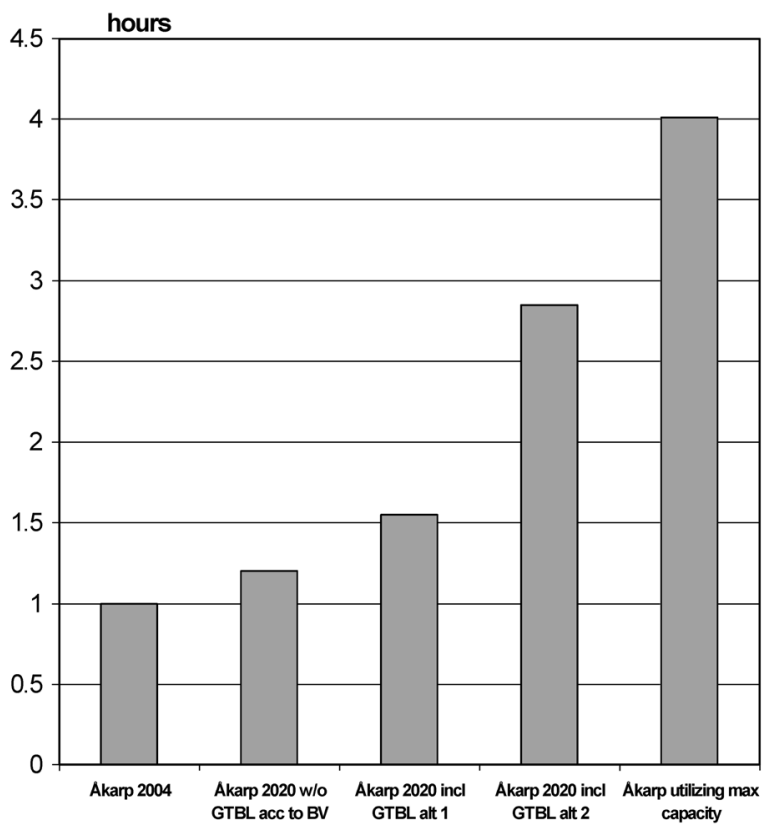

Figure 4. High noise duration in Åkarp for future cases; BV = Banverket, GTBL = Freight Train Bypass Line. surpass the rest of Sweden in terms of high noise duration. The second and third bars of Figure 4 correspond to Banverket's forecast for number of trains by 2020, as also seen in Table 3.

The fourth bar, a second alternative regarding the Freight Train Bypass Line, corresponds to a noise calculation made by Banverket concerning a case in which freight traffic is assumed to be twice that of the first alternative. In the second alternative, equivalent noise is affected by 2 decibels, an increase characterized by the Banverket noise consultant as a "barely audible change." The high noise duration, however, increases by 1 hour and 20 minutes. This increase alone is almost three times that of the total high noise duration of the other train routes with the heaviest traffic loads in Sweden; see comparisons in Figures 3 and 4. In this case, the total number of trains amounts to 590-690 trains per 24 hours. Even so, the four-track capacity is not fully taken into account.

The fifth bar indicates a further increase potential of 200300 trains that would fill the maximum capacity, expected to be reached sometime from 2040-2060. Depending on the combination of train types, the high noise ratio may amount to a total of four hours out of 24 .

One may ask how Banverket can allow themselves to choose a forecasting period as imminent as the year 2020 when the track capacity is filled to only slightly more than half by that date. Furthermore, doing so is in violation of the Swedish Environmental Code, which now has ruled that noise protection must be adjusted for fu- 
ture full-scale traffic, even if such traffic quantities lie far in the future.

\section{Discussion}

\section{Confusion Regarding Different Research Results}

How, then, is it possible for the Banverket consultant to claim that an additional $30-40$ freight trains is potentially an "extremely marginal change in impact" and that a further addition of 120 freight trains amounts to a "barely audible change"? Professor Tor Kihlman (2005) declares this to be a clear error, a confusion of audiometric tests and equivalent noise calculations.

Equivalent sound intensity level is tested when a test subject makes a direct comparison between two sounds interchangeably presented to him or her, reporting the perceived difference between the two. In this test, a 10-decibel increase is perceived as a twofold increase and an increase of 3 decibels is required to perceive a change. Three decibels is technically a doubling of the noise energy. The curve is, thus, logarithmical. Equivalent noise, on the other hand, is the average noise during a longer period of time. If a comparison is made between a variety of cases involving alternative traffic intensities, that is, different frequencies and lengths of trains, and the point of departure is that the fleet of train cars produce equivalent amounts of noise in the various cases, then the disturbance dose is proportional to the combined duration of the noise from the trains passing by.

\section{The Need for New Dose/Response Investigations}

According to Kihlman, new dose/response investigations are necessary to enable calculations of disturbances regarding the substantial traffic quantities occurring between Lund and Malmö, because train traffic of such a magnitude has not been experienced there before. Occupational and environmental health experts are so far unable to express any opinions concerning the effects on public health, as is stipulated in the Swedish Environmental Code.

It seems self-evident that a response would be logarithmical in correspondence with the equivalent sound intensity level test; that is, at already increased noise levels, it takes an ever higher noise increase to be discernible as an increase in noise. Instead, the opposite may apply with regard to equivalent noise from trains; that is, the more often and longer we are interrupted in our conversations by passing trains, the less tolerant we are about accepting yet another train. We may accept being woken up by trains twice a night, but the third occasion may become the straw that breaks the camel's back. In a Berlin study, Babisch et al. (2005) showed a remarkable 30\% increased risk of myocardial infarction in men exposed to $>70 \mathrm{dBA}(6-22$ hours). If the duration of exposure at the same level, $>70$ $\mathrm{dBA}$, lasted more than 10 years, the risk increased to $80 \%$. At a noise level of $60-65 \mathrm{dBA}$, the increased risk after 10 years' exposure was $40 \%$. These results reveal that there may be no such thing as adaptation to noise. On the contrary, research in the fields of occupational and environmental health indicates that one can endure only a certain "life dose" of high stress, and because high traffic noise produces unwanted stress, organisms can accommodate only a limited life dose of high noise.

\section{The Equivalent Noise Guideline Value Needs to Be Adjusted}

Our study of high noise duration also revealed that Sweden has an unreasonably high guideline value for equivalent noise. Although the Malmö-Lund route, as compared with the other most heavily trafficked railway routes in Sweden (Gothenburg, Stockholm, the Frövi-Hallsberg stretch) has twice as much, or more, average noise counted as high noise duration, it is the maximum noise value and not the equivalent noise value that is used as the dimensioning factor for the noise protection investments in Akarp (at least with a calculated traffic increase up to 2020 , the forecasting period in the Banverket railway report). Unless equivalent noise is accepted as the dimensioning factor in Akarp, it may not be used in any other planning situation in Sweden either, because the high noise level is less persistent in other places. This confirms that our equivalent noise guideline value has been set at a very high level and is unparalleled, insofar as it never will be enforced.

The equivalent guideline values applying in Germany are 59 dBA daytime value ( 6 am to $10 \mathrm{pm}$ ) and $49 \mathrm{dBA}$ at night (10 pm to $6 \mathrm{am}$ ) in housing areas, and, for places such as schools and daycare centers, there is a $57 \mathrm{dBA}$ daytime value. Looking at this comparison, there may be cause to recall the joint statement by the Swedish and Danish prime ministers, who said that "the Öresund region will be among the most environmentally friendly regions in Europe." If that goal is to be reached, the equivalent noise guideline value must be lowered considerably. 
Films with Analytical as well as Instructive Impacts

A problem with showing the equivalent noise measure as an average value is that it does not describe how rail traffic produces short sequences of high noise and intervening periods without train noise. The equivalent measure in relation to road traffic noise is slightly more intelligible, because road traffic is more evenly distributed over time. Consequently, comparisons of decibel values for road traffic and rail traffic are difficult. One way of bridging the gap in knowledge is to show the instantaneous noise on film; for example, railway noise can be depicted as foreground noise bubbles moving across a plan map, while road traffic noise is shown as a background image, an integral part of the map.

This is what John Wadbro (2005) has done in a film of Åkarp. His aim is to make road, as well as rail, traffic noise intelligible and comparable in the same film sequence. Four different films have been produced for different noise protection measures: (1) The ground alternative with walls 2 meters high, (2) embedded 1.5 meters plus walls, (3) tunnel alternative $1 \mathrm{~km}$, and (4) tunnel alternative $1.6 \mathrm{~km}$. Wadbro's color scale for the instantaneous noise is identical for road traffic noise and train noise. Consequently, one is not left with a single option of transforming train noise into equivalent noise in order to compare it with road traffic noise. Transforming the sound into a visual image improves our capacity to make the comparisons. To interpret the film, it is important to note that it does not primarily display the dose, that is, the average noise per time unit; however, such a display should be possible in a further developed version. The dose/response investigations originate from the premise that it is the combined dose over a certain period of time that is correlated to the response/ health impact. Can one be certain, however, that the dose measure has the highest correlation with disturbance? Perhaps disturbance is also a function of the frequency of peaks in train noise, or the duration/length of trains, or the distribution between maximum noise and silence. Further studies are required in this area.

\section{Not Only Regulations, but also Local Considerations}

It also must be noted that "guideline values are not legally binding, but must serve as guidance when local factors and special circumstances in each individual case are taken into consideration" (Sahlin, 2005). This article primarily discusses calculation measurements and guideline values, but also deals with special circumstances, such as the need for serene places in one's surroundings. The sonic environment should not only focus on regulating the level of noise exposure, but also on developing quiet places and areas. Recent research has shown that among several environmental characteristics, serenity is key to basic human needs (Grahn, Stigsdotter, and Berggren-Bärring, 2005); however, serenity has not yet become a factor on par with other indicators of a sustainable society.

\section{Conclusion}

The Åkarp case study reveals that the duration of high noise from the railway line between Lund and Malmö, including Åkarp, is double that of other stretches of railway in Sweden. This implies that the maximum noise level of exposure has so far been the dimensioning factor for every other railway project in Sweden. From this it follows that traffic intensity has never weighed heavily into Banverket's calculations concerning noise protection; instead, Banverket has decided upon the same requirements for noise protection nationwide, regardless of the number and length of trains. Ten trains producing an $\mathrm{X}$ decibel noise level have resulted in demands for the same noise protection as 600 trains producing a noise maximum of $\mathrm{X}$ decibels. If the level of maximum noise exposure is equalized at $70 \mathrm{dBA}$, then the total exposure time to the noise of passing trains over a 24 -hour period will be a determining parameter for comparisons between rail traffic noise in different cities. Thus, comparing the duration of high noise exposure is relevant and far easier to understand than is the comparing of equivalent noise values; therefore it is more appropriate from a democratic perspective.

The case study also exemplifies how the difficulty in assessing long-term traffic development has led Banverket to choose a somewhat short-term forecast period with a relatively moderate traffic development and, therefore, to suggest relatively limited noise protection. Judgments passed in Swedish Environmental Code cases have ordained, however, that traffic installation noise protection must be based on full use of the installation, irrespective of the time it takes for full use to appear. The study concludes, among other things, that the "bonus" of $5 \mathrm{dBA}$ is not relevant today, because some rail sections in urban areas show high frequency use at night.

Recent research shows a significant increase in myocardial infarction associated with long-term high noise exposure (Babisch et al., 2005). Examples of "local factors and special 
circumstances" that must be taken into consideration are overlapping noises from other sources, such as nearby motorways, as well as local climatic phenomena-for example, ground inversion that may sometimes cause exceptional sound amplification. The value of public access to quiet and peaceful places, where inhabitants can satisfy their needs for relaxation, for hearing natural sounds, and the like, is also elucidated by the case study.

Public involvement in planning is critical to democratic outcomes. People must understand the technical issues (in this case, analysis of sound) if they are to participate in shaping public policy. This is only possible when the issues are presented in terms that make sense to the layperson. I have tried to show the kinds of questions for which the public requires answers, if they are to understand issues surrounding sound levels. The use of equivalent noise for rail traffic estimations is a special point of democratic weakness in the planning process. Using the more informative, accessible high noise parameter is a complementary option. I also have demonstrated how the film medium can be useful in illustrating comparisons between road and train traffic noise and in making alternative solutions for future rail traffic situations more intelligible.

\section{Note}

1. Decibels adjusted (dBA), also called "A-weighted decibels," refers to the expression of the relative loudness of sounds in air as perceived by the human ear.

\section{References}

Babisch, W., B. Beule, M. Schust, N. Kersten, and H. Ising. 2005. Traffic Noise and Risk of Myocardial Infarction. Epidemiology 16(1):33-40.
Banverket. 2004. Södra Stambanan [Southern Trunk Line], Håstad-Arlöv, MKB [EIR]. 2004-09-14. Banverket, Borlange, Sweden.

Dufort, J. B. 2004. The Noise in Akarp. Large Projects LPo358, Department of Landscape Planning, Swedish University of Agricultural Sciences, Alnarp, Sweden. http://kurs.slu.se/kurser/LP0358/10086.0405/JeanBenoit DUFORT.pdf.

Economic Commission for Europe. 2003. Protocol on Strategic Environmental Assessment of the United Nations and Economic Commission for Europe. ECE/MP.EIA/2003/3, Article 1a.

Grahn, P., U. Stigsdotter, and A.-M. Berggren-Bärring. 2005. A Planning Tool for Designing Sustainable and Healthy Cities: The Importance of Experienced Characteristics in Urban Green Open Spaces for People's Health and Well-Being. In conference proceedings, Quality and Significance of Green Urban Areas, Van Hall Larenstein University of Professional Education, Velp, The Netherlands, April 14-15.

Inregia. 2005. Samhällsutveckling och Transportsystem i Malmö-Lundområdet [Urban and Transport Development of the Malmö-Lund Area]. Inregia, Sweden.

Kihlman, T. 2005. Betr Tågbuller i Akarp [About Train Noise in Akarp]. 2005-09-27. Göteborg, Sweden.

Öhrström, E., and L. Barregård. 2005. Investigating Health Effects Related to Noise from Roads, Trains and Aircraft in the Municipality of Lerum [Undersökning av Hälsoeffekter av Buller från Vägtrafik, Tåg och Flyg $i$ Lerums Kommun]. ISSN 1400-5808. Göteborg University, Sweden.

Sahlin, M. 2005. Skrivning till Riksdagen [Memorandum to the Swedish Parliament]. M2005/3963/Bo. Minister of City Planning, Stockholm, Sweden.

Wadbro, J. 2005. Student assignment for the course, "Stora Projekt." Department of Landscape Planning, Swedish University of Agricultural Sciences, Alnarp, Sweden. http://www.burlov.se/kommunens_service/ bygg_anlaggningsforv/yttrande_SSB/bullerfilm/b.ullerfilm.htm.

World Health Organization. 2001. Occupational and Community Noise. Fact Sheet 258. World Health Organization, Geneva, Switzerland.

Submitted March 21, 2006; revised April 10, 2007; accepted April 24, 2007. 